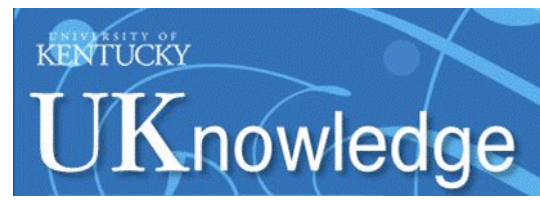

University of Kentucky

UKnowledge

Toxicology and Cancer Biology Faculty

Publications

Toxicology and Cancer Biology

8-2016

\title{
Simultaneous Quantitation of Oxidized and Reduced Glutathione via LC-MS/MS: An Insight into the Redox State of Hematopoietic Stem Cells
}

\author{
Dustin W. Carroll \\ University of Kentucky, dca225@uky.edu \\ Diana Howard \\ Wake Forest University \\ Haining Zhu \\ University of Kentucky, haining@uky.edu \\ Christian M. Paumi \\ Eastern Kentucky University \\ Mary Vore \\ University of Kentucky, maryv@uky.edu
}

Follow this and additional works at: https://uknowledge.uky.edu/toxicology_facpub

I next page for additional authors

Part of the Cell and Developmental Biology Commons, and the Medical Toxicology Commons

Right click to open a feedback form in a new tab to let us know how this document benefits you.

\section{Repository Citation}

Carroll, Dustin W.; Howard, Diana; Zhu, Haining; Paumi, Christian M.; Vore, Mary; Bondada, Subbarao; Liang, Ying; Wang, Chi; and St. Clair, Daret K., "Simultaneous Quantitation of Oxidized and Reduced Glutathione via LC-MS/MS: An Insight into the Redox State of Hematopoietic Stem Cells" (2016). Toxicology and Cancer Biology Faculty Publications. 76.

https://uknowledge.uky.edu/toxicology_facpub/76

This Article is brought to you for free and open access by the Toxicology and Cancer Biology at UKnowledge. It has been accepted for inclusion in Toxicology and Cancer Biology Faculty Publications by an authorized administrator of UKnowledge. For more information, please contact UKnowledge@lsv.uky.edu. 


\section{Simultaneous Quantitation of Oxidized and Reduced Glutathione via LC-MS/MS: An Insight into the Redox State of Hematopoietic Stem Cells}

Digital Object Identifier (DOI)

https://doi.org/10.1016/j.freeradbiomed.2016.05.005

Notes/Citation Information

Published in Free Radical Biology and Medicine, v. 97, p. 85-94.

(C) 2016 Elsevier Inc. All rights reserved.

This manuscript version is made available under the CC-BY-NC-ND 4.0 license

http://creativecommons.org/licenses/by-nc-nd/4.0/.

The document available for download is the author's post-peer-review final draft of the article.

\section{Authors}

Dustin W. Carroll, Diana Howard, Haining Zhu, Christian M. Paumi, Mary Vore, Subbarao Bondada, Ying Liang, Chi Wang, and Daret K. St. Clair 


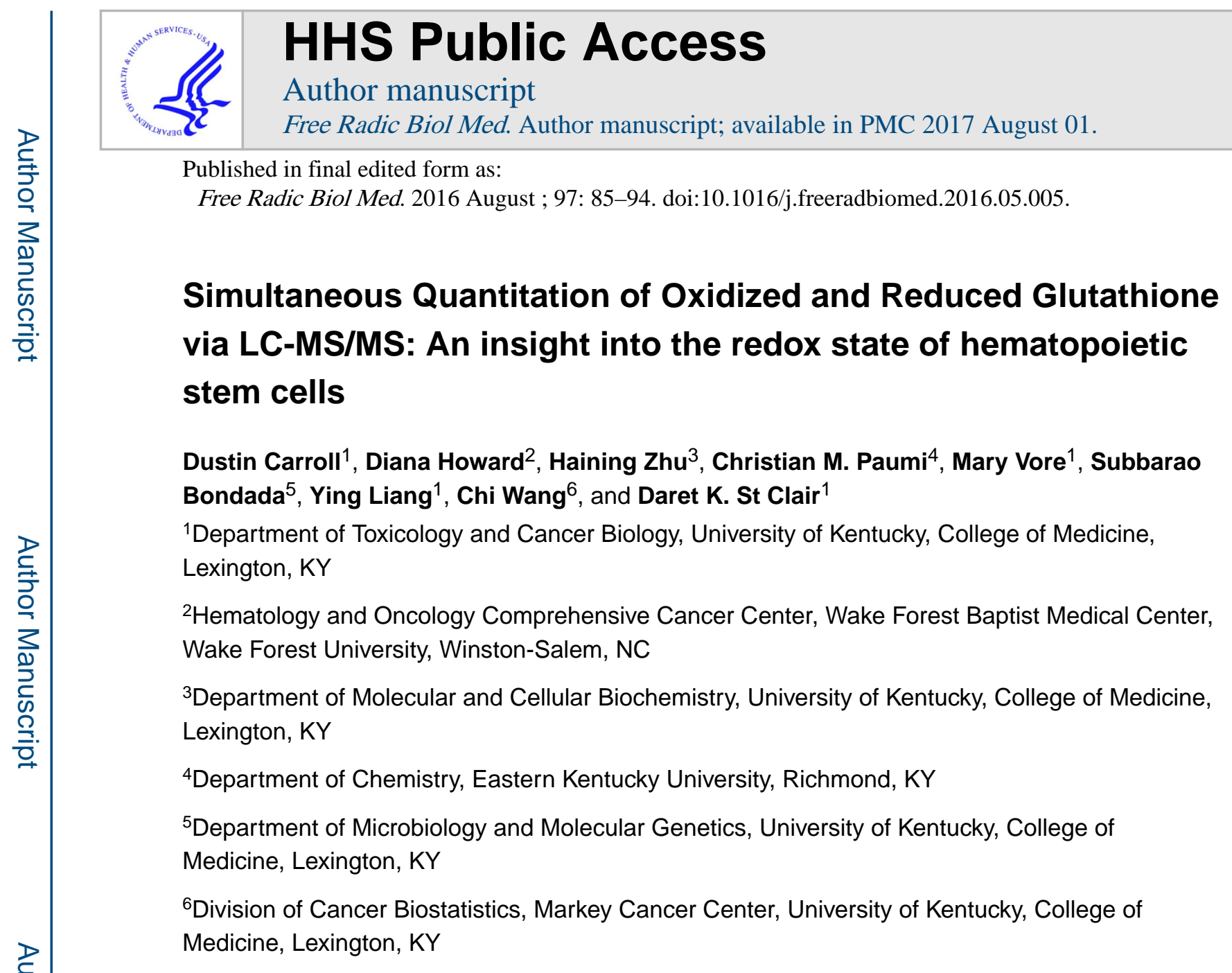

\section{Abstract}

Cellular redox balance plays a significant role in the regulation of hematopoietic stem-progenitor cell (HSC/MPP) self-renewal and differentiation. Unregulated changes in cellular redox homeostasis are associated with the onset of most hematological disorders. However, accurate measurement of the redox state in stem cells is difficult because of the scarcity of HSC/MPPs. Glutathione (GSH) constitutes the most abundant pool of cellular antioxidants. Thus, GSH metabolism may play a critical role in hematological disease onset and progression. A major limitation to studying GSH metabolism in HSC/MPPs has been the inability to measure quantitatively GSH concentrations in small numbers of HSC/MPPs. Current methods used to measure GSH levels not only rely on large numbers of cells, but also rely on the chemical/ structural modification or enzymatic recycling of GSH and therefore are likely to measure only total glutathione content accurately. Here, we describe the validation of a sensitive method used for the direct and simultaneous quantitation of both oxidized and reduced GSH via liquid chromatography followed by tandem mass spectrometry (LC-MS/MS) in HSC/MPPs isolated from bone marrow. The lower limit of quantitation (LLOQ) was determined to be $5.0 \mathrm{ng} / \mathrm{mL}$ for GSH and $1.0 \mathrm{ng} / \mathrm{mL}$ for GSSG with lower limits of detection at $0.5 \mathrm{ng} / \mathrm{mL}$ for both glutathione

Publisher's Disclaimer: This is a PDF file of an unedited manuscript that has been accepted for publication. As a service to our customers we are providing this early version of the manuscript. The manuscript will undergo copyediting, typesetting, and review of the resulting proof before it is published in its final citable form. Please note that during the production process errors may be discovered which could affect the content, and all legal disclaimers that apply to the journal pertain. 
species. Standard addition analysis utilizing mouse bone marrow shows that this method is both sensitive and accurate with reproducible analyte recovery. This method combines a simple extraction with a platform for the high-throughput analysis, allows for efficient determination of GSH/GSSG concentrations within the HSC/MPP populations in mouse, chemotherapeutic treatment conditions within cell culture, and human normal/leukemia patient samples. The data implicate the importance of the modulation of GSH/GSSG redox couple in stem cells related diseases.

\section{Graphical abstract}

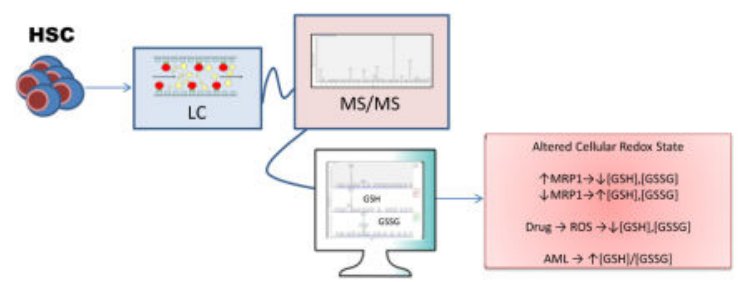

\section{Keywords}

Glutathione; HSC's; LC-MS/MS; Method Validation

\section{Introduction}

Glutathione, $\gamma$-L-glutamyl-L-cysteinylglycine, (GSH) is an endogenous tripeptide involved in many cellular processes including apoptosis, cellular detoxification, and redox signaling[1,2]. Currently, GSH is thought of as a major cellular reducing agent, with high intracellular concentrations reported to range from $0.5-10 \mathrm{mM}$, that aids in protection from ROS mediated injury [3-5]. GSH/GSSG homeostasis is tightly regulated with depletion or oxidation of the cellular GSH pool leading to the activation of anti-oxidant signaling pathways, gene transcription, and GSH synthesis accomplished via glutamate-cysteine ligase (GCL) activity. Oxidizing cellular conditions lead to the heterodimerization of the GCL subunits, GCLC (GCL catalytic subunit) and GCLM (GCL modifier subunit) [6, 7] which, results in increased GCL activity. GSH activity is subsequently regulated via cycling the cysteinyl thiol $(\mathrm{pKa}=9.2)$ through oxidized and reduced states. GSH-mediated cellular detoxification may be accomplished by the direct conjugation of GSH, to xenobiotics and other endogenously produced small molecules via glutathione-S-transferase (GST) activity or through the action of glutathione peroxidase (GPx), which reduces hydrogen peroxide while GSH is co-oxidized to its disulfide form (GSSG)[1, 2, 7, 8]. Additionally, GSH may reversibly modulate cellular redox signaling via direct glutathionylation of thiol groups within redox sensitive signaling proteins. This post-translational modification may also protect thiol groups within redox sensitive signaling proteins from permanent modification under oxidizing conditions $[9,10]$. Similarly, GSH functions to protect mitochondrial 1-Cys peroxiredoxins from damaging oxidation as the resolving thiol group in thioredoxin catalyzed peroxidase activity in saccharomyces cerevisiae [11]. These functions and aspects 
of GSH homeostasis demonstrate the importance of the GSH/GSSG redox pair in the maintenance of the cellular redox state.

The cellular redox state is commonly characterized by examining the ratio of reduced to oxidized species within cellular redox pairs. High intracellular concentrations and redox buffer capacity makes this especially true of the GSH/GSSG redox couple[1, 12-14]. Biochemically, GSH and GSSG may be thought of as components of an electrochemical half-cell in which the flux of single electron transfers can be quantified by their electrical potential or electromotive force, characterizing the proclivity of the GSH/GSSG pair to donate or accept electrons in varying redox states. As a result, defining the individual absolute cellular concentrations of GSH and GSSG and applying these concentrations, along with measured values for intracellular $\mathrm{pH}\left(\mathrm{pH}_{i}\right)$ and cellular volume to the Nernst equation allows for a more specific analysis of the 2GSH/GSSG redox state, the electrical half-cell reduction potential $\left(\mathrm{E}_{h c}\right)[12,13]$. Although living biological systems never rest at a state of equilibrium, characterization of the $2 \mathrm{GSH} / \mathrm{GSSG}$ reduction potential provides a practical snapshot of cellular redox balance[12, 15]. Furthermore, evaluation of the 2GSH/GSSG $E_{h c}$ is a strong indicator of the existing redox state of thiol-containing signaling proteins regulated by glutathione.

The cellular GSH/GSSG ratio is characterized by the equilibrium half-cell reaction of glutathione species resulting in the synthesis of two moles of GSH from the reduction of one mole of GSSG, thus the glutathione based redox state is dependent on cellular GSH concentrations $[12,13]$. Alternatively, the individual concentrations of GSH and GSSG may be considered when characterizing small dynamic changes in the cellular redox state over time. Consequently, an effective evaluation of the glutathione based redox state requires a sensitive and accurate method for the quantitation of absolute concentrations for both GSH and GSSG. This is particularly important for evaluation of the cellular redox state within hematopoietic malignancies manifesting in hematopoietic stem-progenitor cells (HSC/ MPPs); a tissue that has inherently limited availability for study in vivo. For example, in our experience, purification of murine bone marrow typically results in the isolation of approximately 20,000 HSC/MPPs from a single animal that demonstrate the $\mathrm{Lin}^{-}, \mathrm{Sca}_{-} 1^{+}$, c$\mathrm{kit}^{+}$(LSK) phenotype.

HSC/MPP location and function require cellular quiescence and protection from oxidative insult[16-18]. Thus, antioxidant defense is vital to stem cell function. This concept is demonstrated by the increase in stem cell function resulting from treatment with the antioxidant and GSH precursor N-acetylcystiene (NAC)[19]. This is further demonstrated by the major cellular regulator of transcriptional anti-oxidant signaling $\mathrm{Nrf2}$; wherein, $\mathrm{Nrf}^{-/}$ mice are characterized by an increase in HSC/MPP differentiation and a decrease in stem cell function, indicating that a loss of cellular antioxidant machinery is detrimental to the maintenance of HSC/MPP pools in vivo[20]. These observations indicate a potential role for glutathione metabolism and maintenance in the regulation of redox balance and the resulting effect on differentiation and self-renewal, within normal and malignant HSC/MPPs.

It is well recognized that regulation of glutathione metabolism is significantly affected by the expression and activity of the $\mathrm{ABC}$ transporter $\mathrm{ABCC} 1 / \mathrm{MRP} 1$ (multi-drug resistance 
protein 1)[21-24]. MRP1 demonstrates general ubiquitous tissue expression with the exception of the liver hepatocyte, functioning to efflux GSH, GSSG, and glutathione adducted metabolites with a $k_{m}$ in the low $\mathrm{mM}$ range for GSH and $\mathrm{nM}$ to $\mu \mathrm{M}$ range for GS$\mathrm{X}$ adducted metabolites[21-26]. While the role of MRP1 in metabolism within peripheral and specialized tissues has been well documented, the function of MRP1 and its effect on glutathione concentrations as well as the HSC/MPP redox state within primitive HSC's is less understood. This is partially due to the inherently limited availability of lineage primitive hematopoietic tissues, which display low glutathione concentrations in vivo, and is compounded by the lack of sensitive methodologies capable of discerning small dynamic changes in glutathione concentrations within these specialized hematopoietic populations. However, the ability to accurately quantitate cellular GSH pools within these rare tissues is needed because aberrant GSH metabolism may lead to an alteration of the HSC/MPP redox state. These changes in HSC/MPP redox balance are closely associated with genetic instability as well as proliferation, differentiation, and mobility within the HSC/MPP populations in which hematopoietic disorders are thought to initiate and reside[18, 27-29]. As such, examining the GSH/GSSG based HSC/MPP redox state may provide insight to the role of MRP1 and the glutathione redox pair in the onset and progression of hematopoietic neoplasms. Additionally, many cancer therapies, including radiation and chemotherapeutics, such as the anthracyclines, are known to exert a portion of their tumor killing effect through the production of ROS, which may be remediated by adduction of GSH and efflux via MRP1 further altering the malignant cell redox state. Together, these facets indicate that accurate measurement of GSH/GSSG will aid interpretation of MRP1 function in HSC/ MPPs and how alterations in the cellular redox state may affect hematopoietic disease onset, progression, and treatment.

Many current methodologies utilized for GSH and GSSG quantitation are based on free thiol conjugation followed by the observation of a fluorescent product, enzymatic reduction of glutathione disulfide pools, and the chemical derivation of parent glutathione molecules allowing for chromatographic separation[30-34]. These methodologies require complicated chemical reactions, which may not reach completion, and large amounts of sample tissue. Moreover, some methodologies may only accurately measure total glutathione content and are not effective or ideal for accurately quantitating GSH/GSSG in small cell populations in vivo, such as HSC/MPP's. However, emerging methods which combine high performance liquid chromatography with single or tandem mass spectrometry (LC-MS, LC-MS/MS) with and without post column sample modification have quantitated GSH/GSSG in physiological fluids[35, 36]. While these methods demonstrate the potential power of LC-MS/MS analysis, they do so within an effectively unlimited sample population. Here we describe the development and validation of a simple tissue extraction combined with a robust and sensitive LC-MS/MS method, demonstrating high throughput potential, for the direct and simultaneous quantitation of oxidized and reduced forms of glutathione in small HSC/MPP populations. The application of this methodology is demonstrated in cell culture systems as

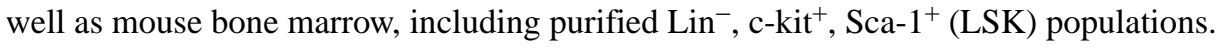
Validation procedures performed were based on the recommended guidelines for LCMS/MS based analysis of small molecules in industry as set forth by the United States Food and Drug Administration[37]. As a method and model control we examine cell populations 
demonstrating differential expression of MRP1 resulting in the characterization of MRP1 functional effect on glutathione concentrations within primitive HSC/MPP populations in vivo. This control allows us to evaluate the ability of our LC-MS/MS method to detect fine variations in glutathione concentrations with both in vitro and in vivo systems. We have found that the over expression of MRP1 in MCF7 cells results in decreased intracellular GSH/GSSG concentrations, while loss of Mrp1 expression in Mrp1-/- HSC/MPPs resulted in the cellular accumulation of GSH and GSSG. These results indicate that MRP1 expression may have a direct impact on the cellular redox state of the HSC/MPP population. Additional evaluation of the utility for this methodology is completed through the quantitation of glutathione within cultured MDSL cells treated with chemotherapeutics (Doxorubicin and Lenalidomide) that have been previously used for the treatment of hematopoietic disorders such as acute myeloid leukemia (AML) or myelodysplastic syndromes (MDS). Furthermore, we characterize glutathione concentrations in normal human bone marrow as well as mononuclear cells isolated form patients afflicted with acute myeloid leukemia. We found that acute myeloid leukemic cells derived from human bone marrow demonstrate elevated levels of GSH, indicating a potential mechanism by which leukemic stem cells balance elevated levels of oxidative stress produced during proliferation.

\section{LC-MS/MS Materials}

$\gamma$-L-Glutamyl-L-Cysteinyl-Glycine (GSH), $\gamma$-glutamyl-L-cyteinyl-glycine disulfide (GSSG), ethylenediaminetetraacetic acid (EDTA), were purchased from Sigma-Aldrich (St. Louis, MO). Trichloroacetic acid purchased from J. T. Baker (Center Valley, PA). Chromatographic columns were purchased from Phenomenex (Torrance, CA). HPLC grade solvents were purchased from Fisher Scientific (Pittsburgh, PA). Formic acid and ammonium formate were purchased from Acros Organic (Pittsburgh, PA).

\section{Cell Culture}

MDSL cells were cultured in IMDM media (ATCC; Manassas, VA) supplemented with 20\% FBS (GE Healthcare; Pittsburgh, PA), 1\% penicillin/streptomycin (Life Technologies; Grand Island, NY), and $15 \mathrm{ng} / \mathrm{mL}$ recombinant human IL-3 (Peprotech; Rocky Hill, NJ). MDSL cells were cultured at both $5 \%$ and $21 \% \mathrm{O}_{2}, 5 \% \mathrm{CO}_{2}$, at $37^{\circ} \mathrm{C}$. MCF7 cells were cultured in DMEM media (Life Technologies; Grand Island, NY) supplemented with 10\% FBS and 1\% penicillin/streptomycin in $5 \% \mathrm{CO}_{2}$ at $37^{\circ} \mathrm{C}$. MRP1 overexpressing MCF7 (MRP1-10, a gift from Dr. Charles Morrow, National Institute of Health, Bethesda, Washington DC) cells were cultured in DMEM media supplemented with 10\% FBS and 1\% penicillin/ streptomycin, $1.0 \mathrm{mg} / \mathrm{mL} \mathrm{G} 418$, in $5 \% \mathrm{CO}_{2}$ at $37^{\circ} \mathrm{C}$.

\section{LC-MS/MS Methodology}

Mass spectrometric analysis was performed on a TSQ Vantage triple quadrupole mass spectrometer (Thermo Fisher Scientific, Waltham MA) coupled with an ion max electrospray ionization source containing a HESI II probe operated in positive ion mode. The GSH/GSSG MS/MS method development was accomplish by direct infusion of a GSH/ GSSG standard $(10 \mu \mathrm{g} / \mathrm{mL})$ into the mass spectrometer at a flow rate of $5 \mu \mathrm{L} / \mathrm{min}$. Single reaction monitoring (SRM) was used to simultaneously analyze samples for GSH and GSSG. The SRM's for GSH (m/z $308.022 \rightarrow \mathrm{m} / \mathrm{z} 84.056+162.002)$ and GSSG (m/z 
$613.99 \rightarrow \mathrm{m} / \mathrm{z} 231.034+354.993$ ) were completed with collision energies and S-lens voltages optimized for each individual transition. Other MS/MS method settings follow: Q1 and Q3 resolution at 0.7 FWHM, scan width at $0.1 \mathrm{amu}$, scan rate at 0.1 seconds, and collision gas pressure at 1.0 mTorr. Tune parameters were as follows: spray voltage at 2700 $\mathrm{V}$, vaporizer temperature at $200^{\circ} \mathrm{C}$, capillary temperature at $250^{\circ} \mathrm{C}$, sheath and auxiliary gas pressures at 35 and 10 arbitrary units respectively. Liquid chromatography was performed on a Shimadzu LC system containing a CMB-2A controller, a SIL-2A auto sampler, and two LC-20 AD pumps (Canby, OR). Liquid chromatographic separation of $10 \mu \mathrm{L}$ sample injections were achieved on a Phenomenex Luna PFP(2) analytical column (100 mm x 2.0 $\mathrm{mm}, 3 \mu \mathrm{m})$ and completed under isocratic conditions, $99 \%$ mobile phase $\mathrm{A}\left(\mathrm{H}_{2} \mathrm{O}, 0.75 \mathrm{mM}\right.$ ammonium formate, $0.01 \%$ formic acid), $1 \%$ solvent $B$ (methanol) at $250 \mu \mathrm{L} / \mathrm{minute}$ over an 11 minute total run time.

\section{Calibration Standards and Quality Control's}

Stock solutions of GSH and GSSG were prepared at $1 \mathrm{mg} / \mathrm{mL}$ by dissolving $1.0 \mathrm{mg}$ of pure powder stock in $1.0 \mathrm{~mL}$ of $2 \%$ TCA ( $1 \mathrm{mM}$ EDTA). One hundred $\mu \mathrm{L}$ aliquots were then frozen at $-80^{\circ} \mathrm{C}$ for no more than 7 days. Working stock solutions were created by 1:10 serial dilutions of the $1.0 \mathrm{mg} / \mathrm{mL}$ stock solutions in $2 \%$ TCA (1mM EDTA). A working GSH/GSSG stock solution was mixed at $10 \mu \mathrm{g} / \mathrm{mL}$ and subsequently used to dilute working standard concentrations of 500.0, 250.0, 100.0, 50.0, 25.0, 10.0, 7.5, 5.0, 2.5, 1.0, 0.5 ng/mL for simultaneous GSH/GSSG standardization of the LC-MS/MS system. QC solutions of $5.0,25.0$, and $250.0 \mathrm{ng} / \mathrm{mL}$ (five injections at each concentration) were also diluted from the $10 \mu \mathrm{g} / \mathrm{mL}$ working GSH/GSSG stock solution. Standard curves and QC's were prepared and run on each day of analysis. Data acquisition and sample peak integration analysis was completed with Xcalibur software, version 2.1 (Thermo Fisher). Standard, QC, and sample concentrations were calculated with sample peak areas and linear equations (form $\mathrm{y}=\mathrm{mx}+$ b) generated by external standard curves for both GSH and GSSG.

\section{Sample Extraction Methodology}

Samples, prepared as described below were pelleted in a $5 \mathrm{~mL}$ round bottom tube by centrifugation in a swinging bucket rotor at $1300 \mathrm{rpm}$ for five minutes. Supernatants were carefully discarded by vacuum aspiration. Cells were then re-suspended in $75 \mu \mathrm{L}$ of extraction buffer (2\% TCA; $1.0 \mathrm{mM}$ EDTA) and incubated on ice for 15 minutes after which samples were vortexed for 45 seconds and incubated on ice for a further 15 minutes. Sample pH was adjusted to 2.0 by mixing $50 \mu \mathrm{L}$ of sample lysate with $50 \mu \mathrm{L}$ of Mobile phase A (HPLC grade $\mathrm{H}_{2} \mathrm{O}, 0.75 \mathrm{mM}$ ammonium formate, $0.01 \%$ formic acid, $\mathrm{pH}=3.0$ ) and cellular debris was subsequently pelleted by centrifugation at $4,000 \mathrm{x} g$ for 10 minutes. Supernatants were collected for LC-MS/MS analysis.

\section{Method Validation}

The linear range of detection for both GSH and GSSG was determined and validated by the analysis of the standard curve and QC samples generated as described above $(\mathrm{n}=3)$. A linear regression was used to determine the correlation coefficient $\left(\mathrm{r}^{2}\right.$ value) after plotting the analyte peak area over the standard concentration. The inter-day slope precision was 
expressed as the percent of the coefficient of variance $\left(\% C V=\frac{\sigma}{\mu} * 100\right)$. Analyte stability at various temperatures was determined by repeat analysis at the lowest $\mathrm{QC}$ concentration $(n=5)$ and is presented as percent of the concentration originally measured. Inter and intraday precision was determined by repeat standard and QC evaluation at three different concentrations within the determined linear range in replicates of five $(n=3)$. Again, precision is presented as \% CV. The lower limit of detection (LLOD) was determined by the lowest peak height that generated a signal to noise ratio $(\mathrm{S} / \mathrm{N})$ greater than or equal to three ( $/ \mathrm{N} \geq 3$ ) for both GSH and GSSG. The lower limit of quantitation (LLOQ) for both analyte species was identified as the minimum analyte concentration required to generate a signal to noise ratio greater than or equal to five $(\mathrm{S} / \mathrm{N} \geq 5)$ as determined by standard addition analysis described below.

Because GSH and GSSG are produced endogenously, the cellular lysates produced during sample extraction serve as the biological matrix. Thus, precision, accuracy and percent recovery were evaluated by standard addition of known analyte concentrations to whole cell lysates which were extracted at 30,000 cells per aliquot of lysate. Mouse whole bone marrow was used for cross validation. Here, individual lysates of 30,000 cells/sample were spiked with known amounts of standard GSH/GSSG solution. To accomplish standard addition of MDSL cell lysates, 1.2 million MDSL cells were lysed in $3.0 \mathrm{~mL}$ of extraction buffer (30,000 cells/ $75 \mu \mathrm{L}$ of extraction buffer). Then, $75 \mu \mathrm{L}$ of lysate was added to $75 \mu \mathrm{L}$ of blank extraction buffer or extraction buffer containing four times the target analyte (GSH/ GSSG) concentration and samples were then incubated on ice for 30 minutes. After incubation, sample $\mathrm{pH}$ was adjusted to 2.0 by mixing $50 \mu \mathrm{L}$ of sample containing the blank lysate, $+/-$ standard with $50 \mu \mathrm{L}$ of mobile phase A. Samples were then spun down as previously described and analyzed via LC-MS/MS. Standard addition of mouse whole bone marrow was completed by preparing individual aliquots of 30,000 cells to which $75 \mu \mathrm{L}$ of either blank extraction buffer or extraction buffer containing two times the target analyte concentration of GSH/GSSG was added. Samples were then incubated on ice for 15 minutes after which the samples were vortexed for 45 seconds each, followed by another 15 minute incubation period on ice. Cellular debris was then pelleted by centrifugation at 4,000 x $g$, and the supernatants were collected for LC-MS/MS analysis. Standard addition for both cell types was completed at 4 concentrations; $0.0,5.0,50.0,250.0 \mathrm{ng} / \mathrm{mL}$ for GSH and 0.0, 1.0, $5.0,50.0 \mathrm{ng} / \mathrm{mL}$ for GSSG. Each standard addition concentration was evaluated in replicates of $n=5$. Target analyte concentrations were evaluated by subtracting the basal GSH/GSSG concentrations obtained by LC-MS/MS analysis of the blank samples from the GSH/GSSG concentrations calculated from the standard addition samples. Precision values at each standard addition concentration are expressed as $\% \mathrm{CV}$, described above. Accuracy values are expressed as \% bias, which is taken as the percent deviation of the determined experimental concentration from the proposed theoretical concentration

( $\left.\frac{(\text { Experimental Value-Theoretical Value })}{\text { Theoretical Value }} * 100\right)$. The percent recovery values were determined as the $\left[\left(\frac{\text { Total Measured Concentration-The Theoretical Standard Concentration }}{\text { Experimental Blank Concentration }}\right) * 100\right]$.

\section{GSH/GSSG Analysis of Cultured Cells}

MRP1 protein expression in MCF7 WT and MRP1 overexpressing MCF7 (MRP1-10) cells was evaluated by flowcytometry analysis after incubation with a FITC conjugated antibody 
targeted to the first nucleotide binding domain (amino acids 617-932) of human ABCC1/ MRP1. MCF7 and MRP1-overexpressing MCF7 (MRP1-10) cells were plated at 100,000 cells per well in 12 well plates and were subsequently incubated in $5 \% \mathrm{CO}_{2}$ at $37^{\circ} \mathrm{C}$ for 24 hours to allow for cellular attachment. Cells were then mechanically harvested, counted by hemocytometer and 50,000 cells per sample were aliquoted into $500 \mu \mathrm{L}$ of $\mathrm{PBS}(\mathrm{pH}=7.0$ for LC-MS/MS analysis of GSH/GSSG as described above. Similarly, prior to analysis, MDSL cells were plated at 200,000 cells $/ \mathrm{mL}$ in a 24 well plate and were then incubated in $5 \%$ or $21 \% \mathrm{O}_{2}, 5 \% \mathrm{CO}_{2}$, at $37^{\circ} \mathrm{C}$ for 24 hours. Cells were then counted by hemocytometer and samples were diluted in $500 \mu \mathrm{L}$ of PBS (pH=7.0) prior to LC-MS/MS analysis of GSH/ GSSG. Total GSH and GSSG concentrations ( $\mathrm{ng} / \mathrm{mL}$ ) were converted to $\mathrm{ng} / \mathrm{sample}$ by multiplying by total sample volume, sample concentrations were then divided by the total number of cells extracted, normalized to 20,000 cells per sample and reported as [GSH] and [GSSG] in ng/20,000 cells.

\section{LSK Purification by FACS Analysis}

Femurs and tibias were harvested from wild type (WT) and Mrp1 knock out (KO) mice of the C57BL/6 background. Subsequently, bone marrow was aspirated with FACS buffer (PBS, 2\% HI-FBS pH=7.4) using a $2 \mathrm{~mL}$ syringe and a 27.5 gauge needle (BD biosciences, San Jose, CA). Whole bone marrow was then pelleted by centrifugation at $1600 \mathrm{rpm}$ for 3 minutes and the supernatant was discarded. Cells were then washed twice with FACS buffer. Whole bone marrow was then re-suspended in red blood cell lysis buffer $(150 \mathrm{mM} \mathrm{NH} 4 \mathrm{Cl}$, 10mM NaHCO3, $1 \mathrm{mM}$ EDTA), filtered through a $5 \mathrm{~mL}(12 \times 75 \mathrm{~mm})$ polystyrene roundbottom tube with a cell strainer cap (BD Falcon, San Diego, CA) and incubated on ice for 5 minutes. Cells were then spun down at $1600 \mathrm{rpm}$ for 3 minutes and the supernatant was discarded. Cells were then washed twice with FACS buffer and re-suspended in $100 \mu \mathrm{L}$ of FACS buffer. After re-suspension cells were incubated with $2 \mu \mathrm{L}$ (1:50 ratio) of conjugated antibody corresponding to cell surface markers used for sorting $\mathrm{Lin}^{-}, \mathrm{Sca}-1^{+}, \mathrm{c}-\mathrm{kit}^{+}$ hematopoietic stem cells (LSKs) on ice for 60 minutes. The antibodies used for sorting LSK's were as follows: Sca-1, Ly-6A/E-PE-Cy7; c-kit, CD-117-PerCP-Cy5.5; Lineage, Cd45R-APC-Cy7, Cd3e-APC-Cy7, Ter199-APC-Cy7, Cd19-APC-Cy7, and Cd11b-APC$\mathrm{Cy} 7$ (all Abs listed are raised in rat, anti-mouse and were purchased at $0.2 \mathrm{mg} / \mathrm{mL}$ from BD Pharmigen, San Diego, CA). Subsequent to incubation, cells were washed and then resuspended in $500 \mu \mathrm{L}$ of FACS buffer for fluorescence assisted cell sorting of LSKs at the University of Kentucky flow cytometry facility. There, $\mathrm{Lin}^{-}, \mathrm{Sca}-1^{+}, \mathrm{c}-\mathrm{kit}^{+} \mathrm{HSC} / \mathrm{MPP}$ 's form both WT and Mrp1 KO mice were sorted such that LSKs from two mice were pooled as one animal for GSH/GSSG analysis. Thus, six mice of each genotype were sorted as three separate animals. LSKs were then taken directly to the University of Kentucky proteomics core for analysis of absolute GSH/GSSG concentrations via LC-MS/MS.

\section{Cell Viability}

MDSL cells were plated at a density of 200,000 cells $/ \mathrm{mL}$ in complete MDSL cell medium containing either vehicle or drug (10 $\mu \mathrm{M}$ Lenalidomide, Cayman Chemical, Ann Arbor MI; or $25 \mathrm{nM}$ Doxorubicin, Pfizer, New York, NY) in a 24 well plate and were incubated for 48

hours. Cells were then transferred to $5 \mathrm{~mL}$ round bottom tubes and washed twice with warm HBSS ( $\mathrm{pH}=7.4$ )(Gibco-Thermo Fischer, Waltham, MA). Cells were then re-suspended in 
MTT solution ( $0.5 \mathrm{mg} / \mathrm{mL}$ 3-(4, 5-dimethylthiazolyl-2)-2,5-diphenyltetrazolium bromide, Sigma Aldridge St. Louis, MO; in RPMI media with no phenol red Gibco-Thermo Fischer, Waltham, MA), aliquoted into a 96 well plate, and incubated at $37^{\circ} \mathrm{C}$ for 4 hours. Equal volumes of lysis buffer (50/50, v/v, isopropanol/DMSO) were added to each well followed by a 30 minute incubation at $37^{\circ} \mathrm{C}$. Samples were then evaluated for absorbance at 560 and $690 \mathrm{~nm}$ using a Molecular Devices SpectraMax Plus 384 plate reader with SoftMax Pro software.

\section{Therapeutic Drug Treatments}

MDSL cells were plated at a density of 200,000 cells $/ \mathrm{mL}$ in complete MDSL cell medium containing either vehicle or drug ( $10 \mu \mathrm{M}$ Lenalidomide, Cayman Chemical, Ann Arbor MI; or $25 \mathrm{nM}$ doxorubicin, Pfizer, New York, NY) in a 24 well plate and were incubated for 6 hours. Samples were then transferred to $5 \mathrm{~mL}$ round bottom centrifuge tubes, extracted, and GSH/GSSG concentrations were analyzed via LC-MS/MS as previously described.

\section{Patient Sample Collection and Analysis}

Peripheral blood and bone marrow samples were obtained by Dr. Diana Howard, from the Markey Cancer Center after individuals gave informed consent for tissue donation. White blood cells were isolated by ficol gradient centrifugation as follows; patient tissue $(21 \mathrm{~mL}$ of blood or bone marrow) was diluted to $50 \mathrm{~mL}$ with phosphate buffered saline (sigma Aldridge). Samples were then layered over $13 \mathrm{~mL}$ of Histopaque (Sigma Aldridge) and centrifuged at $1400 \mathrm{rpm}$ for 45 minutes. The white blood cell layer was then carefully removed, diluted in freezing media (IMDM, 10\% FBS, 1\% penicillin/streptomycin, 10\% DMSO) and stored in liquid nitrogen $\left(-180^{\circ} \mathrm{C}\right)$ until the time of LC-MS/MS analysis as described above.

\section{Results}

\section{LC-MS/MS Method Development and Validation}

Past liquid chromatographic separation of glutathione has been accomplished with common reverse phase $\mathrm{C} 18$ columns. However, we have found that GSH retention on these analytical columns is minimal. Recently, Squellerio et al., described utilization of the Luna PFP-2 reverse phase column (Phenomenex) for the efficient retention of both glutathione species in the LC-MS/MS analysis of GSH and GSSG from human whole blood samples. In agreement with their findings, we found the Luna PFP-2 column to the optimal tool for chromatographic retention and separation of the oxidized and reduced glutathione species. While previous mass spectrometric based methodologies for the analysis of GSH/GSSG in physiological fluids have been characterized, these methods are applied to the analysis of samples for which there effectively is a nearly unlimited supply[35, 36]. To our knowledge, none have examined the limits of sensitivity and potential for analysis of fine changes in GSH/GSSG concentrations within rare and limited tissue populations, such as hematopoietic stem cells in vivo.

To determine the quantitative limit for tissue sample analysis of GSH/GSSG concentrations in vitro and demonstrate the effectiveness and sensitivity of these analytical parameters in 
vivo, we developed a modified LC-MS/MS method for direct and simultaneous GSH/GSSG quantitation. The product ion spectra obtained were evaluated by the comparison to product ion spectra acquired from the direct infusion of pure GSH/GSSG standard (figure 1A). The chromatographic resolution of GSH and GSSG was confirmed by the collection and evaluation of full product ion spectra resulting from the analysis of GSH and GSSG from a biological sample (figure 1B). Upon completion of the LC-MS/MS SRM method development, the average retention times for GSH and GSSG elution from the Luna-PFP2 reverse phase column, calculated from QC analysis were $2.69+/-0.02$ and $4.37+/-0.03$ minutes respectively (mean $+/-\mathrm{SD}, \mathrm{n}=15$ ). A typical extracted ion chromatogram obtained from LC-MS/MS analysis of a $25 \mathrm{ng} / \mathrm{mL}$ standard is shown in Figure 2. Figure 3 demonstrates the typical results obtained from GSH/GSSG standard curve analysis. Although separate external GSH and GSSG standard curves are generated, standard data acquisition occurred simultaneously.

The method validation summary (Table 1) includes all parameters for LC-MS/MS method validation as recommended by the USFDA[37]. The lower limit of detection for both GSH and GSSG was $0.5 \mathrm{ng} / \mathrm{mL}$ as demonstrated by chromatographic peaks that have a signal to noise ratio greater than 3. Precision, lower limits of quantitation (LLOQ) as determined by accuracy measurements at various QC concentrations, and analyte recovery were all determined by standard addition analysis. The lower limits of analyte quantitation were 5.0 $\mathrm{ng} / \mathrm{mL}$ for GSH and $1.0 \mathrm{ng} / \mathrm{mL}$ for GSSG.

The USFDA recommends that accuracy values, which are defined as the closeness of a concentration value obtained by the analytical method to the actual concentration value, and precision values, defined as the closeness of individual measures of an analyte when the procedure is applied to multiple aliquots of a single homogenous solution of biological matrix, must be evaluated at three different concentrations within the analyte's linear range and must have five repeat evaluations at each concentration. These analyte evaluations must have mean coefficient of variance values within $15 \%$ at medium and high concentrations within the analyte's linear range, and $20 \%$ at the LLOQ[37]. Table 1 summarizes the results of this LC-MS/MS method validation. Analyte stability was evaluated at the lowest QC concentration $(5 \mathrm{ng} / \mathrm{mL})$ for storage at 3 different temperatures. Our results agree with those previously reported, demonstrating good GSH/GSSG stability within $15 \%$, at $+4^{\circ} \mathrm{C}$ and $-80^{\circ} \mathrm{C}$. However, GSH stability, at the LLOQ, was slightly diminished $(-23 \%)$ at room temperature after a period of 24 hours. Slope and inter/intra-day precision values had coefficient of variance values less than $10 \%$ (Table 1). A full method validation was completed in MDSL cell lysates in which the accuracy values were all within $20 \%$ at the LLOQ (GSH, 17.4\%; GSSG, $-1.6 \%$ ) and medium to high concentrations demonstrated CV values of less than $5 \%$ (Table 1). Precision \% CV values were less than $15 \%$ at all concentrations for both GSH and GSSG. Analyte recovery values, evaluated by standard addition, were all within $10 \%$ of full analyte recovery for both GSH and GSSG. Finally, a method cross validation by evaluation of accuracy and precision via standard addition was completed in the mouse whole bone marrow biological matrix. Accuracy and precision coefficient of variance values were determined to be within $15 \%$ at all concentrations for both GSH and GSSG. 


\section{Biological Method Evaluation}

To test the potential for this method to evaluate varying glutathione levels in biological systems, we utilized a system with altered expression of Multidrug Resistance-associated Protein 1 (ABCC1/MRP1). We first measured GSH/GSSG levels in MCF7 wild type cells, known to not express MRP1, and compared these results to the GSH/GSSG measurement within MCF7 cells overexpressing MRP1 (MRP1-10 cells). Differential MRP1 expression levels within the two MCF7 cell lines was confirmed by flow cytometometric analysis of FITC conjugated antibody directed to the first nucleotide binding domain of human MRP1(data not shown). Figure 4 shows that overexpression of MRP1 resulted in a significant decrease in cellular GSH and GSSG concentrations, $-0.50 \mathrm{ng} / 20 \mathrm{k}$ cells for GSH, and $-0.13 \mathrm{ng} / 20 \mathrm{k}$ cells for GSSG ( $\mathrm{p}=0.001)$, and that these changes lead to a significant increase in the GSH/GSSG ratio, +8.42 ( $\mathrm{p}=0.01$, data not shown).

This method was then used to evaluate GSH/GSSG concentrations in the absence of MRP1 in vivo. Both WT and Mrp1 ${ }^{-1}-\mathrm{C} 57 \mathrm{BL} / 6$ mice were obtained and their hematopoietic stem cells ( $\mathrm{Lin}^{-}, \mathrm{sca}^{+}{ }^{+}, \mathrm{c}-\mathrm{kit}^{+} ;$LSK's) were isolated via fluoresce assisted cell sorting (Figure 5). The typical yield for this isolation was approximately 20,000 cells from a single animal. The results demonstrated that the LSK cells from $\mathrm{Mrp1}^{-/-}$mice had a significant increase in cellular GSH concentrations $(+4.6 \mathrm{ng} / 20 \mathrm{k}$ cells, $\mathrm{p}=0.01)$. Interestingly, although differences in the GSSG concentration were observed in LSK cells isolated from Mrp1 ${ }^{-/-}$and WT mice, these changes were not judged to be statistically significant (Figure 6). These results demonstrate the robustness and sensitivity of our LC-MS/MS methodology and its ability to detect fine differences in GSH/GSSG concentrations within very limited tissue populations.

Both the over expression and knock out of Mrp1 expression within various cell types resulted in an increase of the GSH/GSSG ratio. This indicates that the evaluation of the individual cellular concentrations of GSH and GSSG and not only their concentration ratio is useful for an accurate interpretation of the GSH/GSSG based cellular redox state.

To further validate the utility of the methodology, MDSL cells were evaluated for GSH and GSSG concentrations after treatment in vitro with two clinically relevant chemotherapeutic agents, Doxorubicin (Adriamycin) and Lenalidomide (Revlimid). Traditionally, high risk MDS patients presenting with blast crisis have been treated with high dose Cytarabine plus an additional course of an anthracycline such as Doxorubicin. Because Doxorubicin is a known ROS inducer, due its metabolic formation of an intermediate semi-quinone structure, we compare the treatment effect and generation of ROS via doxorubicin to that of Lenalidomide. Lenalidomide is known to act as an anti-inflammatory agent as well as a stimulant of lymphocytes and erythropoiesis [38-41]. However, there is evidence that suggests Lenalidomide can, itself, induce oxidative stress. This is observed in the use of Lenalidomide for the treatment of a multiple myeloma model in which the combination of Lenalidomide and the spin trap, ROS scavenger, phenyl-N-t-butylnitrone (PBN) effectively modulates the transcriptional activation of AP-1 family transcription factors [42]. Recently, Lenalidomide has been proven to be effective in the treatment of MDS mouse models and has a significant cytotoxic effect in vitro, at $10 \mu \mathrm{M}$ [43]. Doxorubicin $(25 \mathrm{nM})$ and Lenalidomide $(10 \mu \mathrm{M})$ treatment of MDSL cells results in $21 \%(\mathrm{p}=0.04)$ and $18 \%(\mathrm{p}=0.02)$ decreases in MDSL cell viability respectively (figure 7). Similar treatment effects are also 
demonstrated on cellular GSH and GSSG concentrations in vitro. A 6 hour treatment of MDSL cells with Doxorubicin resulted in a $19 \%$ depletion of GSH $(-5.72 \mathrm{ng} / 20 \mathrm{k}$ cells, $\mathrm{p}=0.03)$ and a $15 \%(-0.019 \mathrm{ng} / 20 \mathrm{k}$ cells, $\mathrm{p}=0.03)$ depletion of $\mathrm{GSSG}$ compared to vehicle control (figure 8). Similarly, 6 hour in vitro treatment of MDSL cells with Lenalidomide resulted in a $10 \%(-2.09 \mathrm{ng} / 20 \mathrm{k}$ cells, $\mathrm{p}=0.01)$ depletion of GSH and a $15 \%(-0.013 \mathrm{ng} / 20 \mathrm{k}$ cells, $\mathrm{p}=0.02$ ) compared to vehicle controls (figure 8). Because the decreases in GSH and GSSG upon treatment were very fine, there was no significant difference in the GSH/GSSG ratio's between treatment and control groups (data not shown). This again points to the importance of individual species concentration determination rather than the examination of the ratio between the reduced and oxidized forms of glutathione alone. Furthermore, the elucidation of such minor, yet significant, changes in analyte concentration demonstrates the sensitivity and robust nature of this methodology.

\section{Patient Sample Evaluation}

Because cellular GSH/GSSG concentrations could play a significant role in disease onset and progression, changes in cellular GSH/GSSG concentrations and the cellular redox state may potentially serve as a biological marker for disease onset or severity. As such, we set out to evaluate GSH/GSSG concentrations in ficol purified white blood cell populations from patient samples donated by healthy individuals or those who had a confirmed case of a hematopoietic malignancy. We measured GSH/GSSG concentrations in 5 samples collected from healthy bone marrow (NBM), and 6 samples from patients diagnosed with acute myeloid leukemia (AML). Figure 9 shows a significantly higher GSH levels in AML compared to the NBM samples $(+18.57 \mathrm{ng} / \mathrm{mL})$, resulting in an increased GSH/GSSG ratio (+2.87). This elevated GSH/GSSG redox state may compensate for the elevated oxidative stress levels that malignant cells utilize for proliferation and disease progression.

\section{Discussion}

Recently, several mass spectrometric based methodologies have directly evaluated oxidized and reduced glutathione extracted from physiological fluids. These methods have demonstrated the ability to measure GSH/GSSG concentrations without the need for the enzymatic reduction or chemical derivation of glutathione or glutathione disulfide prior to endpoint detection[31, 33, 35, 36]. While effective, previous methods have been applied only to large sample pools in which the limits of sample volume and method sensitivity are not an issue. Following the USFDA Guidance for Industry on Bioanalytical LC-MS/MS Method Validation, we have developed and described the validation of a sensitive and robust LC-MS/MS method for the simultaneous and direct quantitation of the oxidized and reduced forms of glutathione. We apply this methodology to the quantitation of GSH and GSSG at the cellular level, and we use this method to determine the lower limit of tissue volume required for accurate cellular GSH/GSSG quantitation. We have demonstrated the quantitation of cellular GSH/GSSG within the murine stem cell populations and the potential for GSH/GSSG analysis within HSCs derived from an individual animal. Our analyses enable the determination of the physiologically relevant, functional effect of MRP1 expression on the glutathione based redox state within primitive HSC populations. Here, loss of MRP1 expression results in an increase in cellular glutathione concentrations creating a 
more reducing intracellular environment. This result indicates that MRP1 may play an important role in regulating redox balance within HSC's and thus influencing the ability or proclivity for HSCs to self-renew or differentiate into downstream functional populations. Additionally, the ability to detect fine clinically relevant treatment induced variations in glutathione concentrations within hematopoietic tissues, as demonstrated by the treatment of MDSL cells with Doxorubicin and Lenalidomide, show that this methodology may be capable of providing valuable insight to treatment toxicity as well as efficacy as it pertains to the modulation of the cellular redox state in vivo.

Because of the critical role of glutathione in cellular redox balance and signaling, we believe that the tissue extraction and LC-MS/MS method described here will become an important tool for examining how the cellular redox state may affect or be affected by the development and treatment of hematopoietic neoplasms. Based on the data obtained from human samples, we speculate that elevated redox stress within malignant hematopoietic cells may be compensated with elevated levels of GSH and that the altered redox state may support disease onset as well as drive disease progression[44]. The results suggest that there is a potential for the future use of cellular GSH/GSSG concentrations as a bio-marker for hematopoietic cancer; however, a much larger patient cohort must be evaluated.

GSH concentrations in the nucleus account for $10-15 \%$ of total cellular GSH, and 1-2\% of this total cellular GSH pool residing in the nucleus may be resistant to depletion by chemical agents such as L-buthionine-[S,R]-sulfoximine (BSO)[45-49]. Thus, characterization of nuclear GSH concentration and function can indicate GSH utility in nuclear protection from oxidant insult, resulting in the faithful conservation of DNA replication and improved DNA repair capabilities. Similarly, mitochondrial GSH may account for up to $30 \%$ of cellular GSH[1, 8, 50,51]. This mitochondrial pool of GSH protects other sulfhydryl containing proteins and may partially regulate the function of ATPases, transporters, and dehydrogenases by buffering the cellular redox status in the face of oxidative challenge[8]. Due to its sensitivity, our method may be utilized for the evaluation of GSH/GSSG concentrations within separate subcellular fractions, such as nuclear extracts and purified mitochondrial preparations. Future efforts to characterize subcellular GSH pools within rare tissue populations may be accomplished by adopting this LC-MS/MS methodology into an ultra-high pressure liquid chromatographic (UHPLC) system. The features of UHPLCMS/MS analysis result in tighter peak widths and greater peak heights resulting in improved overall analyte sensitivity and higher throughput potential. Utilization and further development of the methods we describe here can have an important impact on redox biology research as it pertains to the development of hematopoietic malignancies in limited and rare tissue populations as well as the impact of redox balance on subcellular function.

\section{Acknowledgments}

This work is supported by NIH training grant T32 ES007266, the Edward P. Evans Foundation, and the the NCI Cancer Center Support Grant P30 CA177558. 


\section{References}

1. Lu SC. Glutathione synthesis. Biochim Biophys Acta. 2013; 1830(5):3143-53. [PubMed: 22995213]

2. Liu Y, et al. Emerging regulatory paradigms in glutathione metabolism. Adv Cancer Res. 2014; 122:69-101. [PubMed: 24974179]

3. Lu SC. Regulation of glutathione synthesis. Mol Aspects Med. 2009; 30(1-2):42-59. [PubMed: 18601945]

4. Kaplowitz N, Aw TY, Ookhtens M. The regulation of hepatic glutathione. Annu Rev Pharmacol Toxicol. 1985; 25:715-44. [PubMed: 3890714]

5. Akerboom TP, Bilzer M, Sies H. The relationship of biliary glutathione disulfide efflux and intracellular glutathione disulfide content in perfused rat liver. J Biol Chem. 1982; 257(8):4248-52. [PubMed: 7068633]

6. Yang H, et al. Tumour necrosis factor alpha induces co-ordinated activation of rat GSH synthetic enzymes via nuclear factor kappaB and activator protein-1. Biochem J. 2005; 391(Pt 2):399-408. [PubMed: 16011481]

7. Ballatori N, et al. Glutathione dysregulation and the etiology and progression of human diseases. Biol Chem. 2009; 390(3):191-214. [PubMed: 19166318]

8. Smith CV, et al. Compartmentation of glutathione: implications for the study of toxicity and disease. Toxicol Appl Pharmacol. 1996; 140(1):1-12. [PubMed: 8806864]

9. Ghezzi P. Regulation of protein function by glutathionylation. Free Radic Res. 2005; 39(6):573-80. [PubMed: 16036334]

10. Dalle-Donne I, et al. S-glutathionylation in protein redox regulation. Free Radic Biol Med. 2007; 43(6):883-98. [PubMed: 17697933]

11. Pedrajas JR, et al. Glutathione Is the Resolving Thiol for Thioredoxin Peroxidase Activity of 1-Cys Peroxiredoxin Without Being Consumed During the Catalytic Cycle. Antioxid Redox Signal. 2016; 24(3):115-28. [PubMed: 26159064]

12. Schafer FQ, Buettner GR. Redox environment of the cell as viewed through the redox state of the glutathione disulfide/glutathione couple. Free Radic Biol Med. 2001; 30(11):1191-212. [PubMed: 11368918]

13. Kirlin WG, et al. Glutathione redox potential in response to differentiation and enzyme inducers. Free Radic Biol Med. 1999; 27(11-12):1208-18. [PubMed: 10641713]

14. Asensi M, et al. Ratio of reduced to oxidized glutathione as indicator of oxidative stress status and DNA damage. Methods Enzymol. 1999; 299:267-76. [PubMed: 9916205]

15. Flohe L. The fairytale of the GSSG/GSH redox potential. Biochim Biophys Acta. 2013; 1830(5): 3139-42. [PubMed: 23127894]

16. Suda T, Arai F, Hirao A. Hematopoietic stem cells and their niche. Trends Immunol. 2005; 26(8): 426-33. [PubMed: 15979407]

17. Parmar K, et al. Distribution of hematopoietic stem cells in the bone marrow according to regional hypoxia. Proc Natl Acad Sci U S A. 2007; 104(13):5431-6. [PubMed: 17374716]

18. Jang YY, Sharkis SJ. A low level of reactive oxygen species selects for primitive hematopoietic stem cells that may reside in the low-oxygenic niche. Blood. 2007; 110(8):3056-63. [PubMed: 17595331]

19. Hu L, et al. Antioxidant N-acetyl-L-cysteine increases engraftment of human hematopoietic stem cells in immune-deficient mice. Blood. 2014; 124(20):e45-8. [PubMed: 25287706]

20. Tsai JJ, et al. Nrf2 regulates haematopoietic stem cell function. Nat Cell Biol. 2013; 15(3):309-16. [PubMed: 23434824]

21. Leslie EM, Deeley RG, Cole SP. Multidrug resistance proteins: role of P-glycoprotein, MRP1, MRP2, and BCRP (ABCG2) in tissue defense. Toxicol Appl Pharmacol. 2005; 204(3):216-37. [PubMed: 15845415]

22. Leslie EM, Deeley RG, Cole SP. Toxicological relevance of the multidrug resistance protein 1 , MRP1 (ABCC1) and related transporters. Toxicology. 2001; 167(1):3-23. [PubMed: 11557126] 
23. Keppler D. Export pumps for glutathione S-conjugates. Free Radic Biol Med. 1999; 27(9-10):98591. [PubMed: 10569630]

24. Borst P, Elferink RO. Mammalian ABC transporters in health and disease. Annu Rev Biochem. 2002; 71:537-92. [PubMed: 12045106]

25. Mueller CF, et al. Role of the multidrug resistance protein-1 (MRP1) for endothelial progenitor cell function and survival. J Mol Cell Cardiol. 2010; 49(3):482-9. [PubMed: 20206183]

26. Ellison I, Richie JP Jr. Mechanisms of glutathione disulfide efflux from erythrocytes. Biochem Pharmacol. 2012; 83(1):164-9. [PubMed: 21964344]

27. Tothova Z, et al. FoxOs are critical mediators of hematopoietic stem cell resistance to physiologic oxidative stress. Cell. 2007; 128(2):325-39. [PubMed: 17254970]

28. Ito K, et al. Reactive oxygen species act through p38 MAPK to limit the lifespan of hematopoietic stem cells. Nat Med. 2006; 12(4):446-51. [PubMed: 16565722]

29. Ito K, et al. Regulation of oxidative stress by ATM is required for self-renewal of haematopoietic stem cells. Nature. 2004; 431(7011):997-1002. [PubMed: 15496926]

30. Robin S, et al. LC-MS determination of oxidized and reduced glutathione in human dermis: a microdialysis study. J Chromatogr B Analyt Technol Biomed Life Sci. 2011; 879(30):3599-606.

31. Norris RL, et al. A sensitive and specific assay for glutathione with potential application to glutathione disulphide, using high-performance liquid chromatography-tandem mass spectrometry. J Chromatogr B Biomed Sci Appl. 2001; 762(1):17-23. [PubMed: 11589454]

32. Camera E, Picardo M. Analytical methods to investigate glutathione and related compounds in biological and pathological processes. J Chromatogr B Analyt Technol Biomed Life Sci. 2002; 781(1-2):181-206.

33. Bouligand $\mathbf{J}$, et al. Liquid chromatography-tandem mass spectrometry assay of reduced and oxidized glutathione and main precursors in mice liver. J Chromatogr B Analyt Technol Biomed Life Sci. 2006; 832(1):67-74.

34. Reed DJ, et al. High-performance liquid chromatography analysis of nanomole levels of glutathione, glutathione disulfide, and related thiols and disulfides. Anal Biochem. 1980; 106(1): 55-62. [PubMed: 7416469]

35. Squellerio I, et al. Direct glutathione quantification in human blood by LC-MS/MS: comparison with HPLC with electrochemical detection. J Pharm Biomed Anal. 2012; 71:111-8. [PubMed: 22947504]

36. Cereser C, et al. Quantitation of reduced and total glutathione at the femtomole level by highperformance liquid chromatography with fluorescence detection: application to red blood cells and cultured fibroblasts. J Chromatogr B Biomed Sci Appl. 2001; 752(1):123-32. [PubMed: 11254186]

37. Administration, U.S.F.a.D. Guidance for Industry Bioanalytical Method Validation. 2013.

38. Corral LG, et al. Differential cytokine modulation and $\mathrm{T}$ cell activation by two distinct classes of thalidomide analogues that are potent inhibitors of TNF-alpha. J Immunol. 1999; 163(1):380-6. [PubMed: 10384139]

39. Matsuoka A, et al. Lenalidomide induces cell death in an MDS-derived cell line with deletion of chromosome $5 q$ by inhibition of cytokinesis. Leukemia. 2010; 24(4):748-55. [PubMed: 20130600]

40. Muller GW, et al. Amino-substituted thalidomide analogs: potent inhibitors of TNF-alpha production. Bioorg Med Chem Lett. 1999; 9(11):1625-30. [PubMed: 10386948]

41. Schafer PH, et al. Enhancement of cytokine production and AP-1 transcriptional activity in T cells by thalidomide-related immunomodulatory drugs. J Pharmacol Exp Ther. 2003; 305(3):1222-32. [PubMed: 12649301]

42. Colla $\mathrm{S}$, et al. The oxidative stress response regulates DKK1 expression through the JNK signaling cascade in multiple myeloma plasma cells. Blood. 2007; 109(10):4470-7. [PubMed: 17255354]

43. Rhyasen GW, et al. An MDS xenograft model utilizing a patient-derived cell line. Leukemia. 2014; 28(5):1142-5. [PubMed: 24326684]

44. Jorgenson TC, Zhong W, Oberley TD. Redox imbalance and biochemical changes in cancer. Cancer Res. 2013; 73(20):6118-23. [PubMed: 23878188] 
45. Tirmenstein MA, Reed DJ. The glutathione status of rat kidney nuclei following administration of buthionine sulfoximine. Biochem Biophys Res Commun. 1988; 155(2):956-61. [PubMed: 3421975]

46. Jevtovic-Todorovic V, Guenthner TM. Depletion of a discrete nuclear glutathione pool by oxidative stress, but not by buthionine sulfoximine. Correlation with enhanced alkylating agent cytotoxicity to human melanoma cells in vitro. Biochem Pharmacol. 1992; 44(7):1383-93. [PubMed: 1417960]

47. Edgren MR. Nuclear glutathione and oxygen enhancement of radiosensitivity. Int J Radiat Biol Relat Stud Phys Chem Med. 1987; 51(1):3-6. [PubMed: 3492467]

48. Edgren M, Revesz L. Compartmentalised depletion of glutathione in cells treated with buthionine sulphoximine. Br J Radiol. 1987; 60(715):723-4. [PubMed: 3620835]

49. Britten RA, et al. The relationship between nuclear glutathione levels and resistance to melphalan in human ovarian tumour cells. Biochem Pharmacol. 1991; 41(4):647-9. [PubMed: 1997012]

50. Meredith MJ, Reed DJ. Status of the mitochondrial pool of glutathione in the isolated hepatocyte. J Biol Chem. 1982; 257(7):3747-53. [PubMed: 7061508]

51. Lu SC. Regulation of hepatic glutathione synthesis: current concepts and controversies. FASEB J. 1999; 13(10):1169-83. [PubMed: 10385608] 


\section{Highlights}

- $\quad$ LC-MS/MS method for the simultaneous analysis of oxidized and reduced glutathione.

- $\quad$ The method is validated based on FDA guidelines in vitro and in vivo systems.

- Detection of glutathione in rare HSPCs and drug induced variations of GSH levels.

- $\quad \mathrm{ABCC} 1$ expression alters intracellular glutathione concentrations within HSPCs.

- Evaluation of glutathione as a potential biomarker for hematopoietic malignancy. 

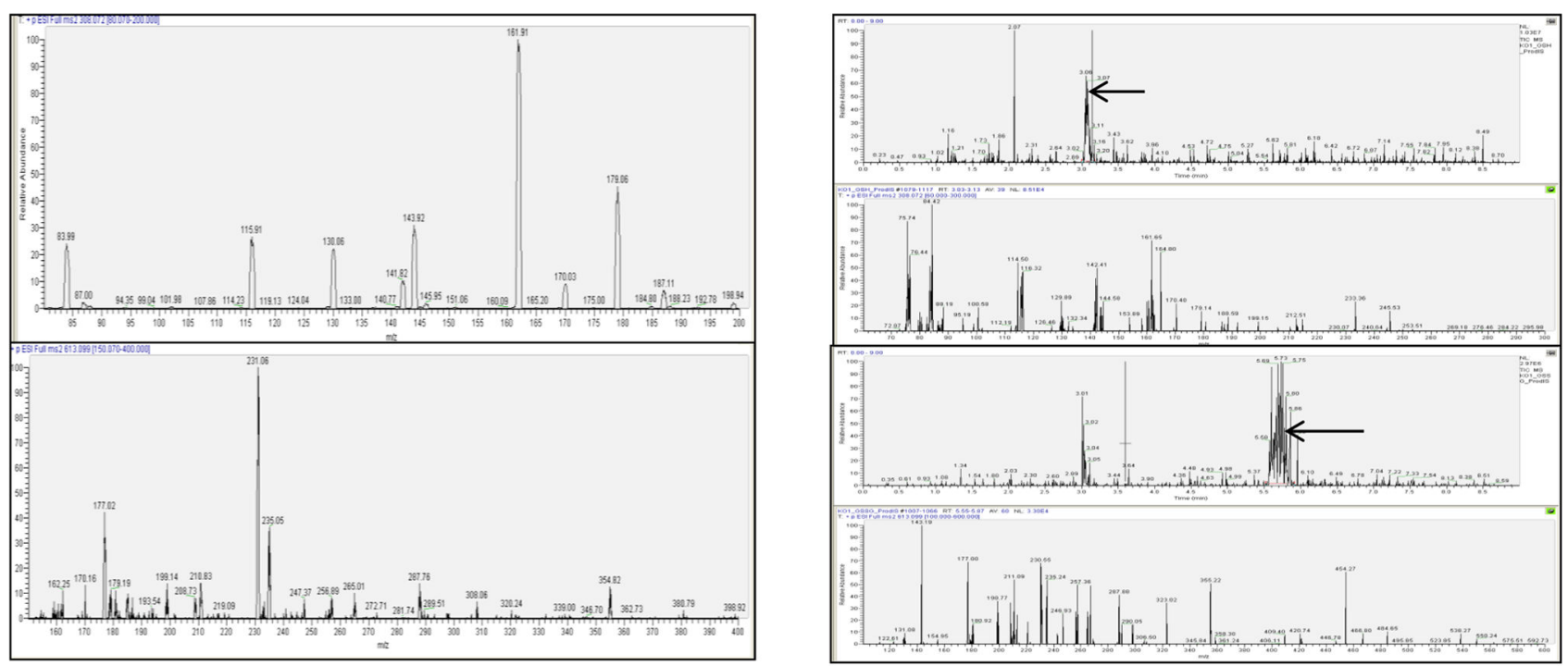

Figure 1.

A.) Both GSH (top) and GSSG (Bottom) were infused in line with a 50\% solvent A, 50\% solvent B LC flow $(200 \mu \mathrm{L} / \mathrm{min})$ at a rate of $5 \mu \mathrm{L} / \mathrm{min}$ and at concentrations of $10 \mu \mathrm{g} / \mathrm{mL}$. The resulting product ion spectra were obtained from GSH and GSSG parent ions. B.) The chromatograms and spectra above resulted from the injection of a cellular extract isolated from mouse LSK cells. The spectra below each chromatogram display the product ion spectrum for the highlighted chromatographic peak above. Comparison of these spectra with the infusion spectra (A) shown above confirm the presence of GSH and GSSG. 


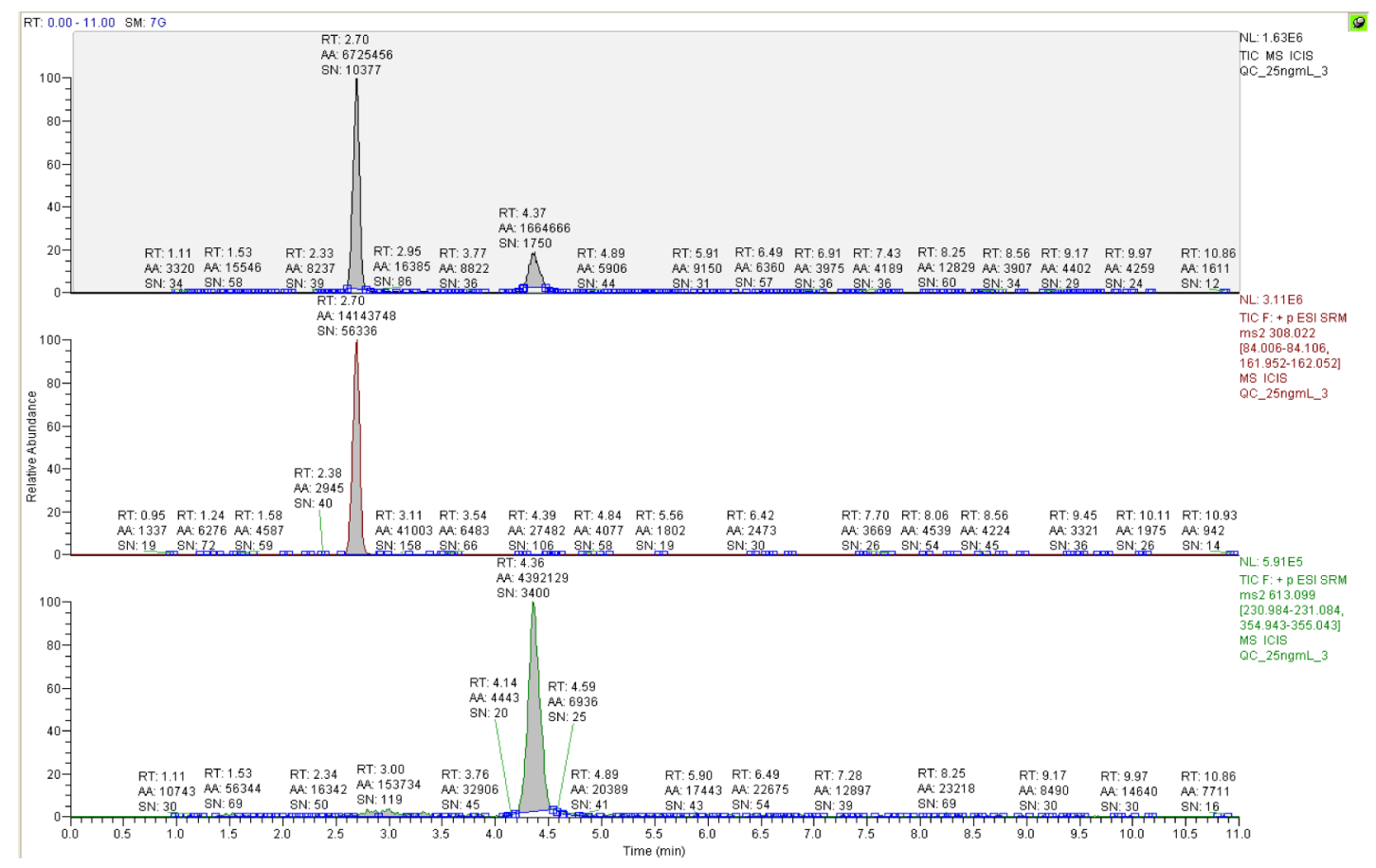

Figure 2.

The chromatograph above demonstrates the simultaneous separation of reduced (GSH, middle) and oxidized (GSSG, bottom) forms of glutathione. This injection sample consisted of $10 \mu \mathrm{l}$ of a $25 \mathrm{ng} / \mathrm{mL}$ QC sample $(0.25 \mathrm{ng}$ on column) routinely run during instrument standardization.

Free Radic Biol Med. Author manuscript; available in PMC 2017 August 01. 


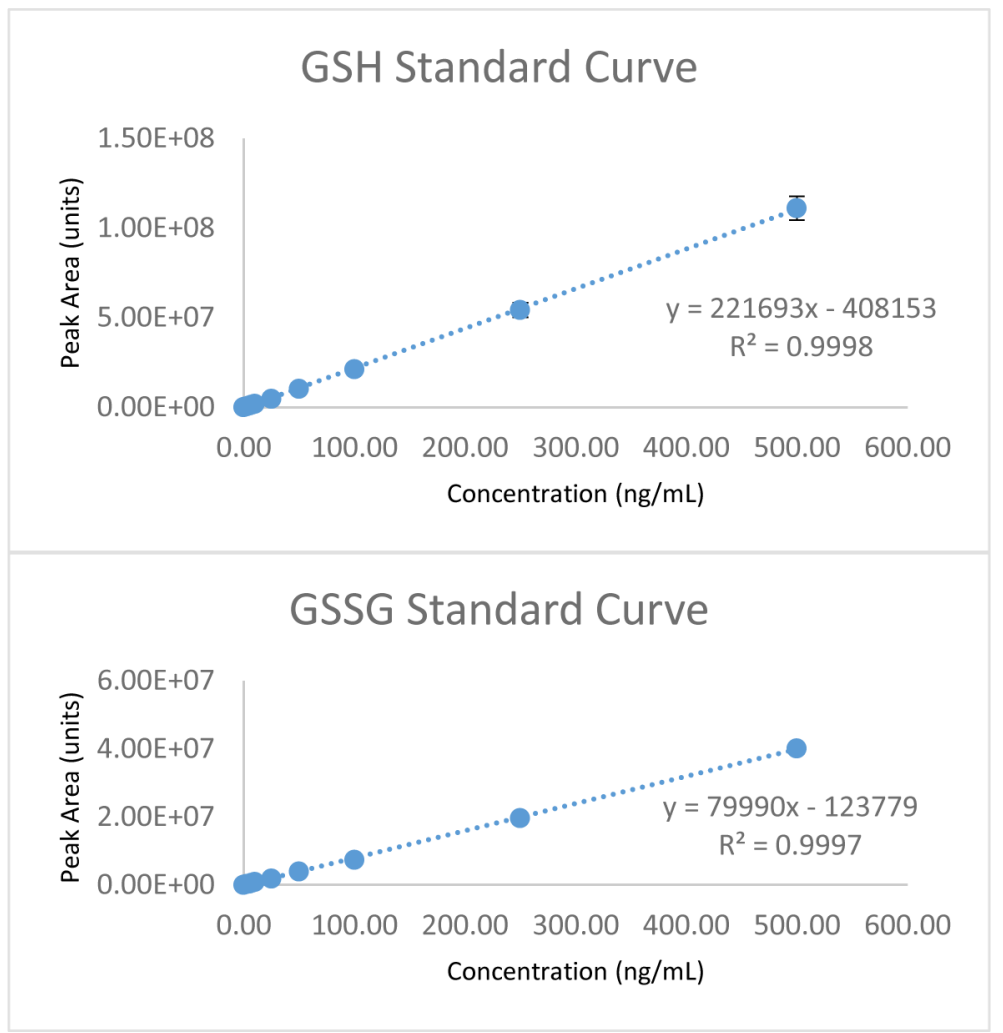

Figure 3.

The linear plots above are examples of typical standard curves for both GSH and GSSG. Although separate curves are generated, GSH and GSSG standardization of the LC-MS/MS system takes place simultaneously. $1 \mathrm{mg} / \mathrm{mL}$ standards for GSH and GSSG are prepared in $1 \%$ TCA (1.0 mM EDTA, 50\% solvent A). These standards are then mixed at $10 \mu \mathrm{g} / \mathrm{mL}$ each and are subsequently diluted down in a stepwise fashion with 1\%TCA (1.0 mM EDTA, $50 \%$ solvent A) to create the working solutions of standard and QC concentrations displayed in the linear range above. Fresh standards and QC's are prepared the day sample analysis takes place. 


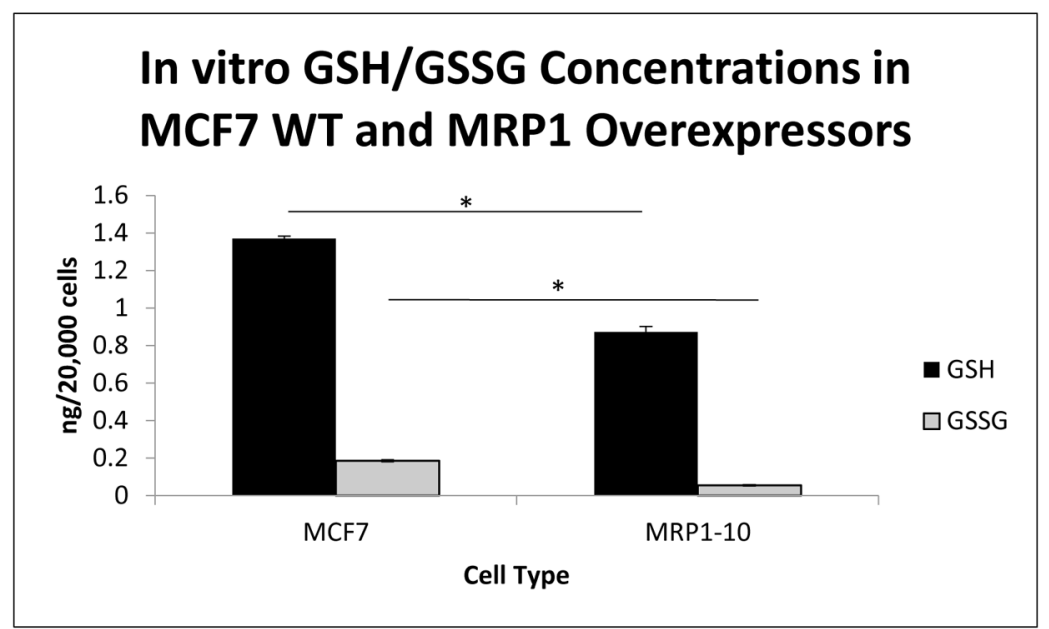

Figure 4.

Mean GSH/GSSG concentrations were evaluated in MCF7 WT and MCF7 cells overexpressing MRP1 (MRP1-10). Significant differences in GSH concentration between MCF7 (1.37 ng/20k cells) and MRP1-10 cells (0.87 ng/20k cells) were determined $(\mathrm{p}=0.001)$. Additionally, significant differences in GSSG concentration between MCF7 (0.19 ng/20k cells) and MRP1-10 cells ( $0.06 \mathrm{ng} / 20 \mathrm{k}$ cells) were determined ( $\mathrm{p}=0.001)$. These changes resulted in a significant alteration to the GSH/GSSG ratio between the two cell lines 7.4 (MCF7) vs 15.82 (MRP1-10) $(\mathrm{p}=0.01)$. 

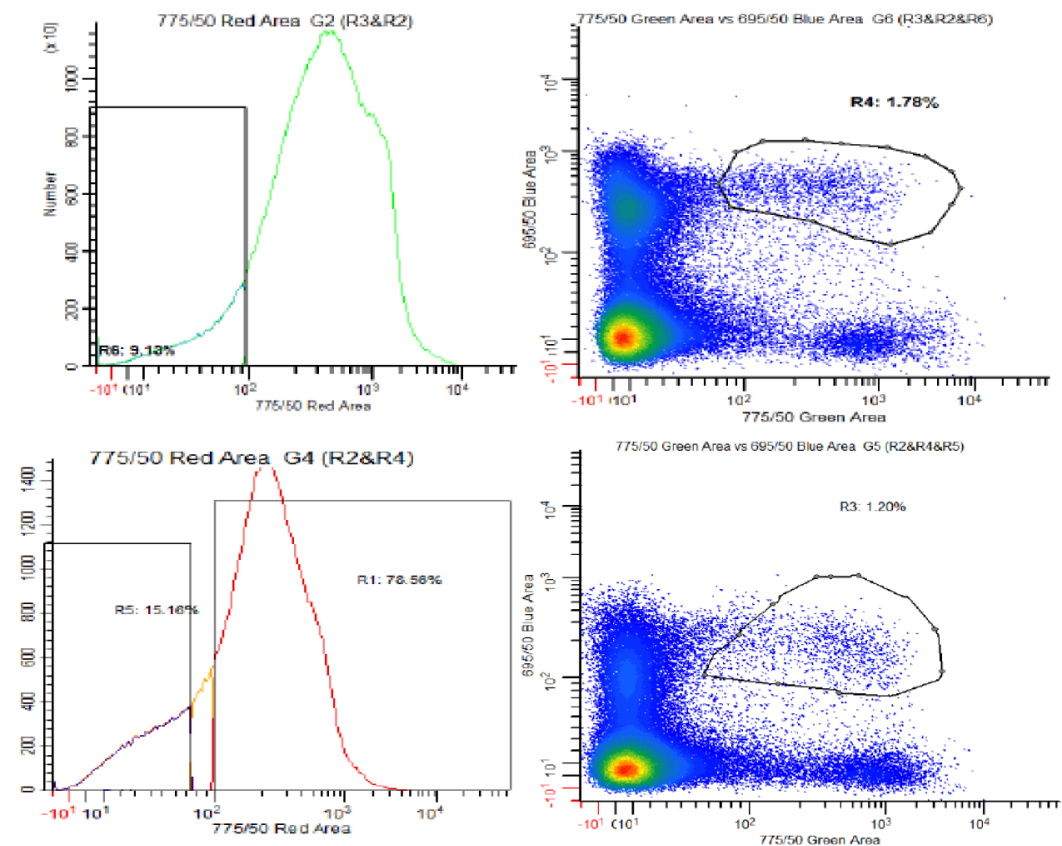

Figure 5.

Fluorescence Assisted Cell Sorting (FACS) purification of $\mathrm{Lin}^{-}, \mathrm{Sca}-1^{+}, \mathrm{c}-\mathrm{kit}^{+}(\mathrm{LSK})$ hematopoietic stem cells (HSC's). Bone marrow from C57BL6 wild type (WT, Bottom) and Mrp1 knock out (KO, Top) mice used for GSH/GSSG analysis. This analysis routinely resulted in the purification of approximately 20,000 cells per mouse. 


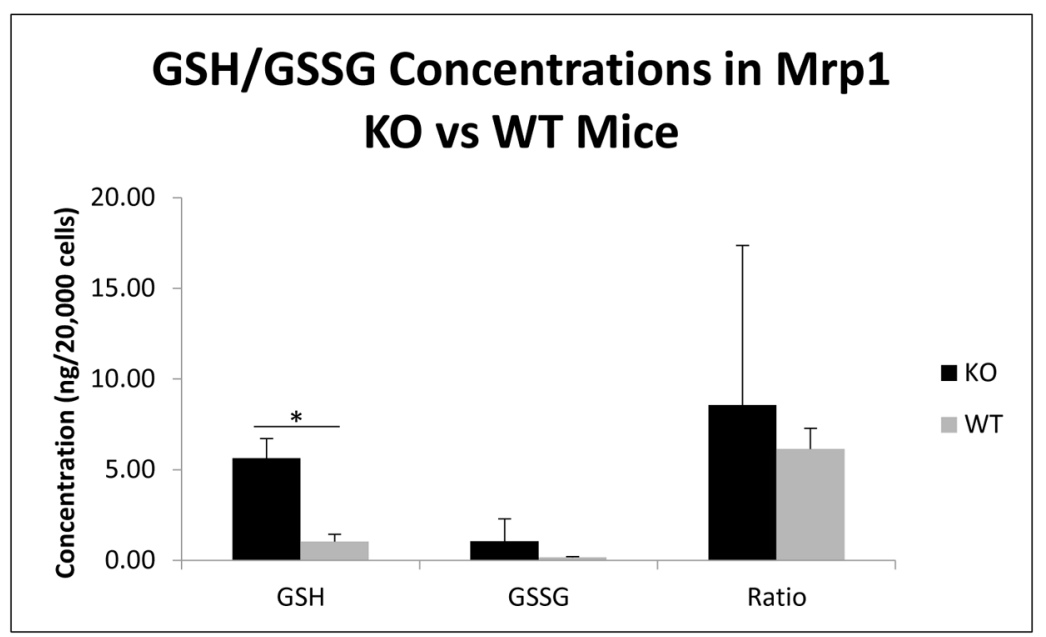

Figure 6.

The concentrations of GSH, GSSG and their cellular ratio determined in WT and Mrp1 KO mouse LSK cells purified as described earlier. The graph depicts the differences in analyte concentrations between genotypes. A significant difference in mean GSH concentration is demonstrated between the Mrp1 KO (5.64 ng/20k cells) and WT (1.04 ng/20k cells) animals $(\mathrm{p}=0.01)$. A difference in the GSSG concentration between genotypes was found (KO, 1.07 ng/20k cells vs WT, $0.17 \mathrm{ng} / 20 \mathrm{k}$ cells) but this difference was not statistically significant. Similarly no significant difference in GSH/GSSG ratios was determined (KO, 8.56 vs WT, 6.16). 


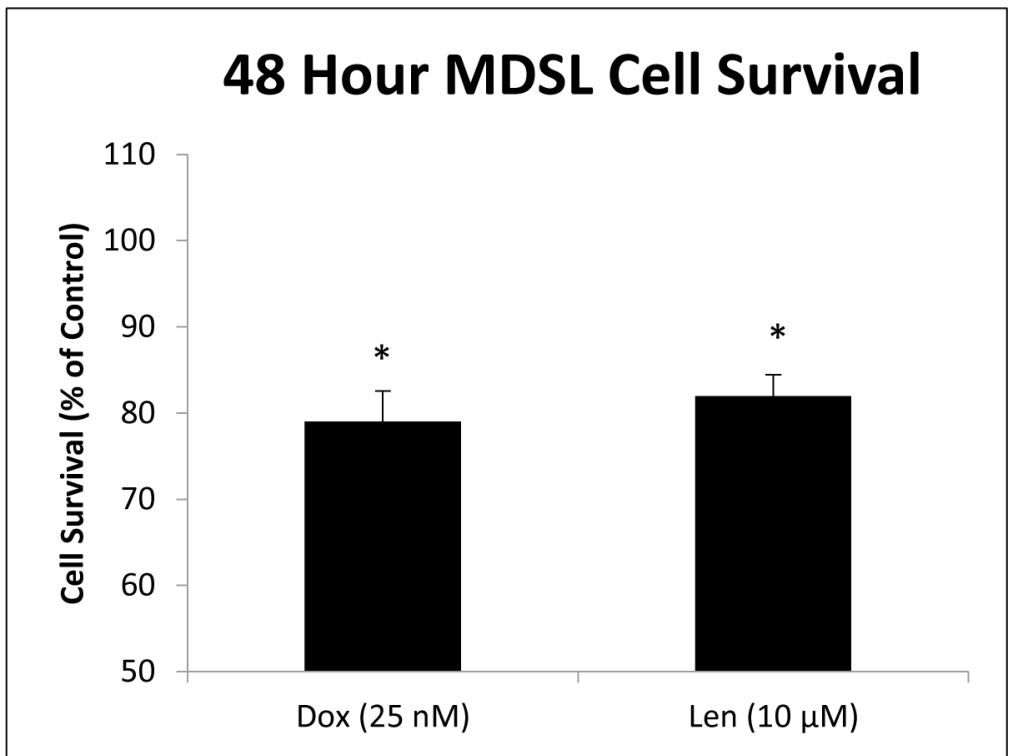

Figure 7.

MDSL cell viability was evaluated via MTT assay after 48 hour treatment with $25 \mathrm{nM}$ Doxorubicin and $10 \mu \mathrm{M}$ Lenalidomide in vitro. Both treatments resulted in a significant decrease of cell survival, $21 \%$ for Doxorubicin $(\mathrm{p}=0.04)$ and $18 \%$ for Lenalidomide $(\mathrm{p}=0.02)$. Results are expressed as percent cell survival normalized to the vehicle control. 


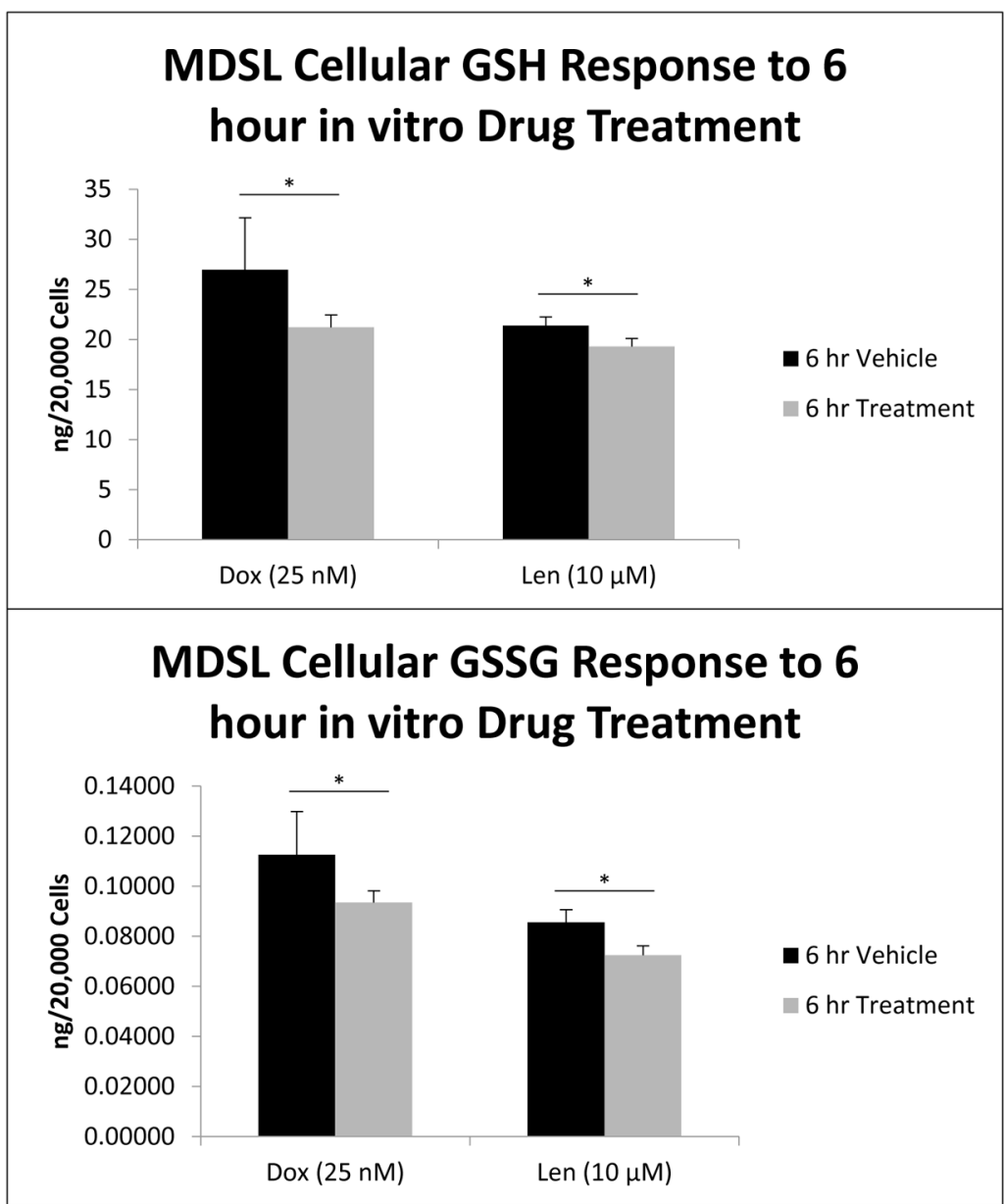

Figure 8.

MDSL cell GSH (A) and GSSG (B) concentrations were analyzed after 6 hour drug treatment in vitro. Both Doxorubicin $(25 \mathrm{nM})$ and Lenalidomide $(10 \mu \mathrm{M})$ caused significant depletion of GSH and GSSG (Dox GSH $-5.72 \mathrm{ng} / 20 \mathrm{k}$ cells, $\mathrm{p}=0.03$; Dox GSSG -0.019 $\mathrm{ng} / 20 \mathrm{k}$ cells, $\mathrm{p}=0.03$; Len GSH $-2.09 \mathrm{ng} / 20 \mathrm{k}$ cells, $\mathrm{p}=0.02$; Len GSSG $-0.013 \mathrm{ng} / 20 \mathrm{k}$ cells $\mathrm{p}=0.01$ ). 


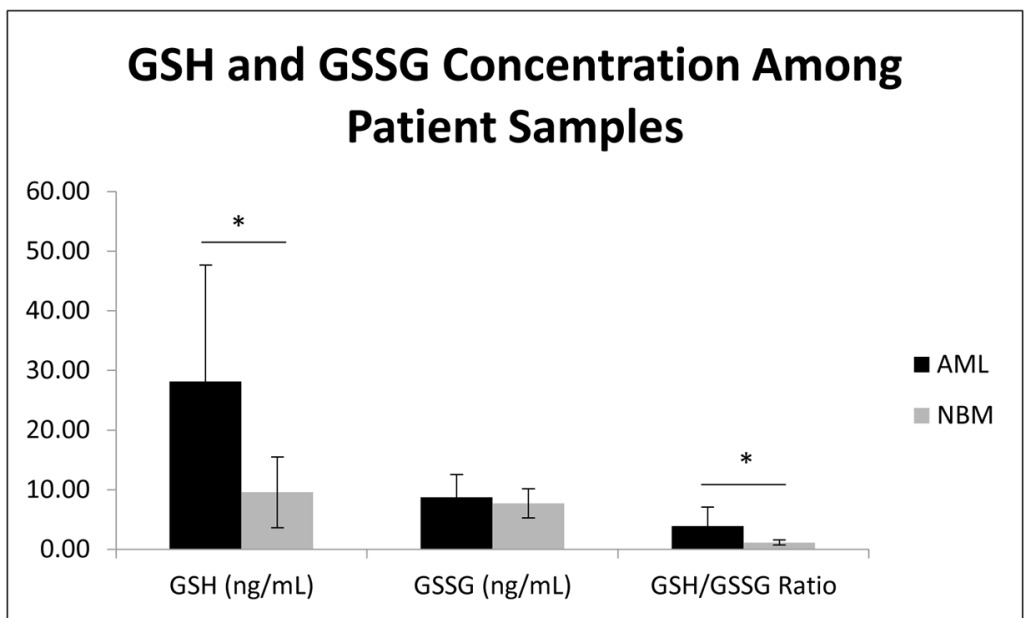

Figure 9.

Mean GSH, GSSG concentrations and their cellular concentration ratio analyzed within lymphocytes purified from the peripheral blood of AML patients as was the bone marrow obtained from normal patient donors. LC-MS/MS analysis revealed a significant increase in GSH concentrations within the AML $(28.15 \mathrm{ng} / \mathrm{mL})$ vs NBM $(9.58 \mathrm{ng} / \mathrm{mL})$ sample populations $(\mathrm{p}=0.03$ ), resulting in a significant increase in the GSH/GSSG ratio, 3.94 in AML vs 1.16 in NBM patients $(\mathrm{p}=0.04)$. No significant difference was determined in GSSG concentrations between patient groups (AML, $8.77 \mathrm{ng} / \mathrm{mL}$ vs NBM, $7.73 \mathrm{ng} / \mathrm{mL}$ ). 


\section{Table 1}

The table above summarizes the results of the LC-MS/MS method validation for the simultaneous analysis of reduced and oxidized forms of glutathione. The Lower Limit of Detection and Quantitation were taken as the concentrations which exhibit a signal greater than or equal to that of three (LLOD) and five (LLOQ) times the intensity of a blank matrix injection respectively. All standards and QC's had an injection volume of $10 \mathrm{uL}$ and were analyzed using the LC-MS/MS method previously summarized. Inter-day standard and slope analysis was completed over 3 days with a linear range of $0-500 \mathrm{ng} / \mathrm{mL}$. QC's levels evaluated were at 5, 25, and 250 $\mathrm{ng} / \mathrm{mL}$ over 3 days for inter-day precision analysis. Intra-day precision analysis was completed with an $\mathrm{n}=5$ for each concentration on the same day.

\begin{tabular}{|c|c|c|}
\hline \multicolumn{3}{|l|}{ Method Validation Summary } \\
\hline Stability $(\%)$ & GSH & GSSG \\
\hline RT (24 hr) & 77 & 91 \\
\hline +4 Deg C (24 hr) & 111 & 94 \\
\hline -80 Deg C (7 Days) & 91 & 95 \\
\hline LLOD (ng/mL) & 0.5 & 0.5 \\
\hline LLOQ (ng/mL) & 5.0 & 1.0 \\
\hline Inter-day St. Curve Slope Precision (\%CV) & 6.2 & 3.5 \\
\hline \multicolumn{3}{|l|}{ Intra-day QC Precision (\% CV) } \\
\hline GSH $5 \mathrm{ng} / \mathrm{mL}$; GSSG, $5 \mathrm{ng} / \mathrm{mL}$ & 4.9 & 6.5 \\
\hline GSH 50 ng/mL; GSSG, $50 \mathrm{ng} / \mathrm{mL}$ & 2.0 & 3.3 \\
\hline GSH $250 \mathrm{ng} / \mathrm{mL} ; \mathrm{GSSG}, 250 \mathrm{ng} / \mathrm{mL}$ & 2.0 & 2.4 \\
\hline \multicolumn{3}{|l|}{ Inter-day QC Precision (\% CV) } \\
\hline GSH $5 \mathrm{ng} / \mathrm{mL}$; GSSG, $5 \mathrm{ng} / \mathrm{mL}$ & 4.3 & 8.7 \\
\hline GSH 50 ng/mL; GSSG, 50 ng/mL & 3.0 & 3.5 \\
\hline GSH 250 ng/mL; GSSG, 250 ng/mL & 1.4 & 2.3 \\
\hline \multicolumn{3}{|c|}{ Accuracy (Mean \% Bias Relative to Theoretical Standard Concentration) } \\
\hline \multicolumn{3}{|l|}{ MDSL Cell Line } \\
\hline GSH $5 \mathrm{ng} / \mathrm{mL} ; \mathrm{GSSG}, 1 \mathrm{ng} / \mathrm{mL}$ & $17.4(5.87 \mathrm{ng} / \mathrm{mL})$ & $-1.6(0.98 \mathrm{ng} / \mathrm{mL})$ \\
\hline GSH $50 \mathrm{ng} / \mathrm{mL}$; GSSG, $5 \mathrm{ng} /$ & $1.1(50.55 \mathrm{ng} / \mathrm{mL})$ & $1.8(5.09 \mathrm{ng} / \mathrm{mL})$ \\
\hline GSH $250 \mathrm{ng} / \mathrm{mL} ; \mathrm{GSSG}, 50 \mathrm{ng} / \mathrm{mL}$ & $1.2(253.06 \mathrm{ng} / \mathrm{mL})$ & $0.1(50.94 \mathrm{ng} / \mathrm{mL})$ \\
\hline \multicolumn{3}{|l|}{ Mouse Whole Bone Marrow } \\
\hline GSH $5 \mathrm{ng} / \mathrm{mL}$; GSSG, $5 \mathrm{ng} / \mathrm{mL}$ & $2.1(5.10 \mathrm{ng} / \mathrm{mL})$ & $0.4(5.07 \mathrm{ng} / \mathrm{mL})$ \\
\hline GSH $50 \mathrm{ng} / \mathrm{mL}$; GSSG, $50 \mathrm{ng} / \mathrm{mL}$ & $-9.7(45.16 \mathrm{ng} / \mathrm{mL})$ & $0.2(50.09 \mathrm{ng} / \mathrm{mL})$ \\
\hline GSH $250 \mathrm{ng} / \mathrm{mL} ; \mathrm{GSSG}, 250 \mathrm{ng} / \mathrm{mL}$ & $-2.4(243.95 \mathrm{ng} / \mathrm{mL})$ & $0.5(251.28 \mathrm{ng} / \mathrm{mL})$ \\
\hline Precision (\% CV) & & \\
\hline
\end{tabular}




\begin{tabular}{|c|c|c|}
\hline Method Validation Summary & & \\
\hline Stability $(\%)$ & GSH & GSSG \\
\hline \multicolumn{3}{|l|}{ MDSL Cell Line } \\
\hline GSH $5 \mathrm{ng} / \mathrm{mL}$; GSSG, $1 \mathrm{ng} / \mathrm{mL}$ & 11.3 & 14.5 \\
\hline GSH $50 \mathrm{ng} / \mathrm{mL}$; GSSG, $5 \mathrm{ng} / \mathrm{mL}$ & 4.3 & 2.4 \\
\hline GSH $250 \mathrm{ng} / \mathrm{mL}$; GSSG, $50 \mathrm{ng} / \mathrm{mL}$ & 1.1 & 1.7 \\
\hline \multicolumn{3}{|l|}{ Mouse Whole Bone Marrow } \\
\hline GSH $5 \mathrm{ng} / \mathrm{mL}$; GSSG, $5 \mathrm{ng} / \mathrm{mL}$ & 13.2 & 5.1 \\
\hline GSH $50 \mathrm{ng} / \mathrm{mL} ; \mathrm{GSSG}, 50 \mathrm{ng} / \mathrm{mL}$ & 7.6 & 1.9 \\
\hline GSH $250 \mathrm{ng} / \mathrm{mL}$; GSSG, $250 \mathrm{ng} / \mathrm{mL}$ & 5.0 & 2.1 \\
\hline \multicolumn{3}{|c|}{ Recovery (\% Compared to Measured Blank Concentration) } \\
\hline \multicolumn{3}{|l|}{ MDSL Cell Line } \\
\hline GSH $5 \mathrm{ng} / \mathrm{mL} ; \mathrm{GSSG}, 1 \mathrm{ng} / \mathrm{mL}$ & 101.5 & 99.6 \\
\hline GSH $50 \mathrm{ng} / \mathrm{mL}$; GSSG, $5 \mathrm{ng} / \mathrm{mL}$ & 100.9 & 102.4 \\
\hline GSH $250 \mathrm{ng} / \mathrm{mL}$; GSSG, $50 \mathrm{ng} / \mathrm{mL}$ & 105.1 & 101.2 \\
\hline
\end{tabular}

